\section{Pseudohypercreatininaemia in two patients caused by monoclonal lgM interference with enzymatic assay of creatinine}

\section{INTRODUCTION}

Creatinine is released into the blood following non-enzymatic hydrolysis of creatine in skeletal muscle, and excreted into urine depending on glomerular filtration. The serum creatinine concentration is widely used as a marker of glomerular function because it increases in patients with decreased glomerular filtration rate (GFR). Although GFR is costly to measure, an estimated GFR (eGFR) can be calculated from the serum creatinine concentration. Since 2006, laboratories have calculated eGFR values using the isotope dilution mass spectrometry traceable modification of diet in renal disease equation. ${ }^{1}$ This standardisation allows direct comparison of creatinine and eGFR results from different laboratories. Reporting of eGFR is a significant advance, but it should be remembered that results are affected by interferences affecting the creatinine assay.

Serum creatinine was initially measured for clinical purposes using alkaline picrate (Jaffé reaction), ${ }^{2}$ but this method is affected by numerous interferents, including bilirubin, ketones, protein and non-creatinine chromogens. ${ }^{3}$ Enzymatic assays were later introduced, which are less susceptible to interference $^{3}$ and more specific being unaffected by non-creatinine chromogens. ${ }^{4}$ However, interference has been reported from 5-fluorocytosine, ethamsylate, dopamine, dobutamine, nitromethane, creatine, sarcosine and ascorbic acid. Hummel et $a l^{5}$ reported positive interference in enzymatic creatinine measurement caused by monoclonal $\operatorname{IgM}$ in three patients with Waldenström's macroglobulinaemia. IgM can precipitate and interfere in the detection step of the reaction. This interference can be avoided by ultrafiltration to remove protein before measuring creatinine. At the time of this publication, most clinical laboratories were measuring creatinine using alkaline picrate assays. However, since the introduction of eGFR, reporting the use of enzymatic assays has become more widespread. It, therefore, seems timely to illustrate this problem by describing two cases recently referred to the renal service.

\section{CASE REPORT 1}

A 71-year-old female was referred by her general practitioner (GP) to a satellite nephrology outpatient clinic for investigation of a serum creatinine of $257 \mu \mathrm{mol} / \mathrm{L}$ (Siemens Advia enzymatic assay). She was well, and there was no significant past medical or renal history. She was not taking any prescribed medications, but did take evening primrose oil, cod liver oil, glucosamine and garlic capsules. Previous blood tests had shown normal glucose and bilirubin concentrations.

Initial investigations were all normal. However, capillary electrophoresis of serum proteins (Sebia UK), showed a discrete monoclonal peak at a concentration of $9 \mathrm{~g} / \mathrm{L}$. Immunofixation (Sebia UK) showed that this was IgM kappa. Most of the IgM present was monoclonal. No monoclonal free light chains were detected in the urine. To determine the cause of the increased serum creatinine, she was invited to the central renal unit for a renal biopsy. Prebiopsy blood tests showed a serum creatinine of $73 \mu \mathrm{mol} / \mathrm{L}$ (Abbott Architect 3 enzymatic assay), and a second specimen analysed by the same method showed a creatinine of $70 \mu \mathrm{mol} / \mathrm{L}$. The apparent decrease in creatinine concentration was initially presumed to represent an episode of acute kidney injury (AKI), of unknown cause, from which, the patient had completely recovered. She was not biopsied.

Following discharge, she remained well, and after 2 weeks, attended the satellite nephrology outpatient clinic for review. The serum creatinine was again increased at $216 \mu \mathrm{mol} / \mathrm{L}$ (Siemens Advia enzymatic assay). To investigate the discrepancy in results, a serum specimen from the patient was sent to three different laboratories, and creatinine measured by three different methods viz Siemens Advia enzymatic assay, Abbott Architect 3 enzymatic assay and picric acid Jaffé (O'Leary) reaction. The results were as shown below in table 1 .

GFR was measured definitively by iohexol clearance and found to be $63 \mathrm{~mL} / \mathrm{min} / 1.73 \mathrm{~m}^{2}$. At this stage, it was clear that the serum creatinine concentration, as measured by the Siemens Advia enzymatic assay, was artefactually increased.

\section{CASE REPORT 2}

A 63-year-old male was referred by his GP to a different satellite general nephrology outpatient clinic for investigation of abnormal renal function. Serum creatinine had been above $300 \mu \mathrm{mol} / \mathrm{L}$ on two occasions (Siemens Advia enzymatic assays). There were no symptoms or signs of renal or systemic disease.

To further investigate this possible AKI, serum protein electrophoresis was performed, which showed an IgM kappa paraprotein at a concentration of $15 \mathrm{~g} / \mathrm{L}$. Total IgM was increased at $20 \mathrm{~g} / \mathrm{L}(0.5-2.0)$, and both $\operatorname{IgA}$ and $\operatorname{IgG}$ were low at $0.41 \mathrm{~g} / \mathrm{L}$ $(0.8-4.0)$ and $5.1 \mathrm{~g} / \mathrm{L}(6.0-16)$, respectively. Capillary electrophoresis of serum proteins (Sebia UK) showed a discrete monoclonal peak. Immunofixation (Sebia UK) showed that this was IgM kappa. The IgM present was entirely monoclonal. Urine immunofixation detected free kappa monoclonal light chains. A bone marrow biopsy showed B cell lymphoma, in keeping with lymphoplasmacytic lymphoma. Subsequently, the patient attended the renal unit for a renal biopsy. However, prebiopsy blood tests showed creatinine $89 \mu \mathrm{mol} / \mathrm{L}$ (Abbott Architect 3 enzymatic assay). This was confirmed by analysis of a second specimen, which showed creatinine $84 \mu \mathrm{mol} / \mathrm{L}$.

A serum specimen was assayed simultaneously by Siemens Advia and Abbott Architect 3 enzymatic assays. The results were as shown below in table 2 .

The discrepancy in creatinine measurements was further investigated by measurement of serum cystatin $\mathrm{C}$ concentration, which was normal at $0.90 \mathrm{mg} / \mathrm{L}$ (reference range <1.4). An eGFR calculated using cystatin C was normal at $105 \mathrm{~mL} / \mathrm{min} /$ $1.73 \mathrm{~m}^{2}{ }^{6}$ A renal biopsy was no longer considered necessary.

\section{DISCUSSION}

In both these cases, the Siemens Advia enzymatic assay consistently gave artefactually high creatinine results.

Table 1 Creatinine and eGFR results obtained from a single sample being analysed by three different methods-Siemens Advia and Abbott Architect 3 enzymatic assays, and picric acid Jaffé reaction

\begin{tabular}{lll}
\hline & Creatinine $(\boldsymbol{\mu m o l} / \mathbf{L})$ & eGFR \\
\hline Siemens Advia enzymatic assay & 257 & 16 \\
Abbott Architect 3 enzymatic assay & $75 / 73$ & $>60 />60$ \\
Picric acid Jaffé & 82 & $>60$ \\
\hline
\end{tabular}

eGFR, estimated glomerular filtration rate. 


\section{PostScript}

Table 2 Creatinine and eGFR results obtained from a single sample being analysed by two different enzymatic assays-Siemens Advia and Abbott Architect 3

\begin{tabular}{lcr}
\hline & Creatinine $(\mu \mathrm{mol} / \mathrm{L})$ & eGFR \\
\hline Siemens Advia enzymatic assay & 282 & 20 \\
Abbott Architect 3 enzymatic assay & 98 & $>60$ \\
\hline eGFR, estimated glomerular filtration rate. & &
\end{tabular}

Compared with the older, alkaline picrate methods, enzymatic assays for creatinine have less frequently been reported to be affected by interference, but there have been reports of interference by $\operatorname{IgG}^{7}$ and $\operatorname{IgM} .^{5}$ In the cases reported here, the discrepancies in creatinine concentrations resulted from pseudohypercreatininaemia, which we believe was caused by positive interference by monoclonal IgM. In the previously published cases, ${ }^{5}$ IgM concentrations ranged from 7.8 to $44 \mathrm{~g} / \mathrm{L}$, whereas the concentrations in the two cases reported here were both at the lower end of this range. This suggests that even low-level IgM paraproteinaemia, such as that present in monoclonal gammopathy of uncertain significance, can interfere significantly with some enzymatic assays. It is not known why this interference was confined to the Siemens Advia method, but other authors have observed that some paraproteins are susceptible to precipitation at a particular assay $\mathrm{pH}^{7}$

Given that IgM paraproteinaemia is not uncommon, and enzymatic assays are now widely used, clinicians are likely to encounter this interference. Pseudohypercreatininaemia caused by
IgM paraproteinaemia should be considered when investigating the cause of an unexplained high serum creatinine concentration, so that inappropriate investigation and diagnostic conundrums can be avoided.

Tracey Salter, ${ }^{1}$ James Marsh, ${ }^{1}$ Bhrigu Sood, ${ }^{1}$ Callum Livingstone, ${ }^{2}$ Hugh Gallagher ${ }^{1}$

${ }^{1}$ South West Thames Renal and Transplantation Unit, St Helier Hospital, Carshalton, Surrey, UK

${ }^{2}$ Clinical Biochemistry Department, Royal Surrey County Hospital, Guildford, Surrey, UK

Correspondence to Dr Tracey Salter, South West Thames Renal and Transplantation Unit, St Helier Hospital, Wrythe Lane, Carshalton, Surrey SM5 1AA, UK; traceysalter@doctors.org.uk

Acknowledgements Dr Marta Lapsley, Dr Niki Meston, Dr David Cartwright and Sarah Gibbs.

Contributors Here, I outline the individual contributions of each coauthor: Myself (TS): I drafted the article, and have been involved in revising it. JM, $B S, C L$ and $H G$ have all revised the article, and given final approval of the version to be published. BS and HG were responsible for the nephrological care of the patients described.

Competing interests None declared.

Patient consent Obtained.

Provenance and peer review Not commissioned; externally peer reviewed.
To cite Salter T, Marsh J, Sood B, et al. I Clin Pathol Published Online First: [please include Day Month Year] doi:10.1136/jclinpath-2015-203064

Received 9 April 2015

Revised 19 May 2015

Accepted 26 May 2015

J Clin Pathol 2015;0:1-2.

doi:10.1136/jclinpath-2015-203064

\section{REFERENCES}

1 Myers GL, Greg Miller W, Coresh J, for the National Kidney Disease Education Program Laboratory Working Group. Recommendations for improving serum creatinine measurement: a report from the laboratory working group of the National Kidney Disease Education Program. Clin Chem 2006;52:5-18.

2 Jaffe M. Uber den Niedersclag, welchen Pikrinsaure in normalem Harn erzeugt und uber eine neue Reaktion des Kreatinins. Z Physiol Chem 1886;10:391-400.

3 Owen LI, Wear JE, Keevil BG. Validation of a liquid chromatography tandem mass spectrometry assay for serum creatinine and comparison with enzymatic and Jaffe methods. Ann Clin Biochem 2006;43:118-23.

4 Lindback B, Berman A. A new commercial method for the enzymatic determination of creatinine in serum and urine evaluated: comparison with a kinetic Jaffe method and isotope dilation-mass spectrometry. Clin Chem 1989;35:835-57.

5 Hummel KM, von Ahsen N, Kuhn RB, et al. Pseudohypercreatininemia due to positive interference in enzymatic creatinine measurements caused by monoclonal IgM in patients with Waldenstrom's macroglobulinemia [Letter]. Nephron 2000;86:188-9.

6 Stevens LA, Coresh J, Schmid CH, et al. Estimating GFR using serum cystatin $\mathrm{C}$ alone and in combination with serum creatinine: a pooled analysis of 3418 individuals with CKD. Am J Kid Dis 2008:51:395-406.

7 Lankireddy S, Ghandour F. Interference by $\lg G$ monoclonal protein in the enzymatic method for creatinine determination. Gund Luth Med J 2007:4:76-8. 


\section{CP Pseudohypercreatininaemia in two patients caused by monoclonal IgM interference with enzymatic assay of creatinine}

Tracey Salter, James Marsh, Bhrigu Sood, Callum Livingstone and Hugh Gallagher

J Clin Pathol published online June 9, 2015

Updated information and services can be found at:

http://jcp.bmj.com/content/early/2015/06/09/jclinpath-2015-203064

\section{These include:}

References This article cites 7 articles, 3 of which you can access for free at: http://jcp.bmj.com/content/early/2015/06/09/jclinpath-2015-203064 \#BIBL

Email alerting Receive free email alerts when new articles cite this article. Sign up in the service box at the top right corner of the online article.

\section{Notes}

To request permissions go to:

http://group.bmj.com/group/rights-licensing/permissions

To order reprints go to:

http://journals.bmj.com/cgi/reprintform

To subscribe to BMJ go to:

http://group.bmj.com/subscribe/ 